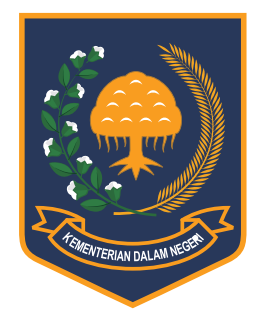

Jurnal Bina Praja 10 (1) (2018): 81-89

Jurnal Bina Praja

e-ISSN: 2503-3360 | p-ISSN: 2085-4323

Accreditation Number

735/AU2/P2MI-LIPI/04/2016

http://jurnal.kemendagri.go.id/index.php/jbp/index

\title{
The Effect of Organization Culture Moderation and Big Five Personality ON THE INFLUENCE OF WORKING Culture TOWARDS The Performance of Jambi Provincial Government Civil SERVANTS
}

\author{
Susi Desmaryani* \\ Regional Research and Development Agency (Balitbangda) Jambi Province \\ Jl. R.M. Noor Admadibrata No. 1A
}

Received: 27 February 2018; Accepted: 6 April 2018; Published online: 12 May 2018

DOI: $10.21787 / j b p .10 .2018 .81-89$

\begin{abstract}
Services provided by civil servants of Jambi Provincial Government is still not as expected by the community. Performance of civil servants is still not yet directed to service oriented. For that reason, work culture must be created that leads to performance achievement supported by the organizational culture and the personality of civil servants themselves in providing services. This study aims to determine: (1) Illustration of Organizational Culture, Big Five Personality as a moderation variable and work culture and performance as a moderated variable. (2) Effect of moderation of organizational culture on the interaction of work culture and civil servant's performance in Jambi Provincial Government, (3) Big Five Personality Moderation effect on the interaction of work culture and civil servant's performance in Jambi Province Government. The types of research are descriptive and verificative. Multistage random sampling technique is sampling in two stages; first, identifying SKPD, Bureau, and Agency, and second, determining the number of respondents from each SKPD, Bureau, and Agency. Data analysis is descriptive and inferential analysis is using path analysis. The results describe the organizational culture descriptively, Big Five personality as moderate variables are in a good category, work culture and performance as moderated variables are in a good category. Even so, organizational culture as a moderating variable is weakening the influence of work culture on performance if compared to direct influence between organizational culture on work and work culture on performance. On the other hand, the moderating variables are able to strengthen the influence of work culture on the performance of civil servants in the Jambi Provincial Government, compared to the Big Five Personality's direct contribution to performance and work culture on performance. Therefore, every Department, Agency, Bureau, and UPTD reassess whether the culture applied is in accordance with the character, personality, and demands of the external environment, so that organizational culture is able to strengthen the influence of work culture on performance.
\end{abstract}

Keywords: Work Culture, Performance, Organizational Culture, Big Five Personality

\section{INTRODUCTION}

This research is about the effect of moderation of organizational culture and Big Five Personality on the influence of work culture on civil servant's performance in Jambi Province Government. Moderation is the term for a third variable that affects the correlation between two variables (Widhiarso, 2011 , p. 1). So, the effect of moderation means that the third variable gives effect to the correlation of two variables. The effect of moderation serves to strengthen or weaken the relationship between independent variables to the dependent variables. In this case, the organizational culture and Big Five Personality is a moderating variable that serves to influence and can strengthen or weaken the relationship of work culture to the performance of civil servants in the Government of Jambi Province. This is in accordance with the opinion of (Liana, 2009, p. 90) which explains that the moderation variable is a variable that can strengthen or weaken the direct relationship between independent variables with dependent variables and have an

\footnotetext{
* Corresponding Author

Phone : +62 81312453338

Email : susidesmaryani@yahoo.com
} 
influence on the nature of the relationship between variables.

In this case, organizational culture and Big Five Personality act as the third variable (moderating variable) that gives effect to work culture on performance. I would first explain how organizational culture variables and Big Five Personality (as independent variables) directly affect performance (as a dependent variable), supported by previous research findings. The results of this study will first prove the direct influence of organizational culture and Big Five Personality on performance also proves the direct influence of Work culture on performance. As a moderating variable, whether organizational culture and big five personality influence more on the interaction between work culture and performance than not as a moderating variable (as an independent variable against dependents)

Organizational culture in the form of rules, values, and working system must be followed in the work, can be in the form of Standard Operating Procedures (SOP) as a guideline for employees in work that aims to reduce the level of error in work, so that the services provided to the community are in accordance with the expectation.

The performance of civil servants should also be supported by an interesting personality. Personality (Big Five Personality) is an important part of a worker, because personality can reflect how a person behaves, generally in everyday life and especially in the world of work and the behavior will emerge a pattern of action (Nasyroh \& Wikansari, 2017, p. 15). Big Five Personality is more to highlight the character possessed by employees in dealing with a job, such as anxious, lazy, or diligent. Therefore, an organization should view the Big Five Personality as a method or means to improve the quality of human resources so that the goal of organizational performance can be achieved. Big Five Personality is used to measure the personality of a person who is able to influence the performance of the organization (Nasyroh \& Wikansari, 2017, p. 15).

From initial observations about organizational culture, Big Five Personality, work culture and performance in some SKPDs in Jambi Provincial Government, most SKPDs have implemented rules, values, work systems, and SOPs that aim to enable employees to work with discipline, order, and rule. However, when organizational culture is implemented in the form of work culture through attitudes and behavior, Raden Mattaher General Hospital Jambi still encountered the nature of the nurses that are less friendly and sometimes badtempered, doctors that are not on time so that patients have to wait for a while. This is in contrast to the existing work culture in the hospital, in which every medical and paramedic should serve with a smile, work meticulously, and on time.

According to surveys in some other SKPDs, there are still encountered unproductive employees, resulting in non-timely employment such as business permits that are still under complained of by people over time delays and so forth. This is also reinforced by Ratuwalangon, Tulusan, \& Londa (2017, pp. 4-6) that people are still complaining about the delay in service processes, unfriendly officers, and unclear information.

Dahmiri's research results (2014, p. 141) support the results of a provisional survey on the performance of civil servants in Jambi conducted in hospitals and some other SKPDs. The results of this study were conducted on civil servants in Sarolangun district Jambi Province where civil servant's performance is still in a bad category related to discipline, responsibility, the speed of service, courtesy, official's friendliness, and uncertainty of service schedule. This situation has an impact on the satisfaction of the community in receiving services. Currently, the public demands a customer-driven public service orientation (Direktorat Aparatur Negara Kementerian Perencanaan Pembangunan Nasional/BAPPENAS, 2010, p. 9). However, the services provided by civil servants to the community are still not in line with expectations.

Public complaints on services provided by civil servants are also reinforced by the results of research by Suryadi (2010, p. 53) which explains public complaints about public services related to procedures and working mechanisms of service that is convoluted, not transparent, less informative, less accommodative, less consistent, limited facilities and infrastructure services, which do not guarantee certainty (legal, time, and cost). This is even worse because the practice of illegal levies and acts that indicate deviations, such as corruption, collusion, and nepotism still exist.

The problems of civil servants behavior who are unfriendly, lazy, careless, and unwilling to increase their own potential reflect the work culture. For that reason, SKPD must create an organizational culture that is able to change attitudes and behavior of human resources so that it has an interesting personality (Big Five Personality). This is in line with the results of a research by Margaretha \& Natalia (2012, p. 153) which describes that Human Resources work has a variety of work attitudes and work behavior. Work attitude contains a positive or negative evaluation of a person about aspects of their work environment. Positive or negative attitude work may affect employee performance.

The variety of work attitude and work behavior that leads to positive and negative work attitude is a work culture that will impact the performance of employees. Therefore, the work culture that is 
Table 1.

The illustration of Civil Servants Education Level in Jambi Province

\begin{tabular}{rlrr} 
No. & Education Level & Amount & \multicolumn{1}{l}{$(\%)$} \\
1. & Primary School & 97 & 1.46 \\
\hline 2. & Junior High School & 153 & 2.30 \\
\hline 3. & Senior High School & 2,032 & 30.60 \\
\hline 4. & Vocational School/ D1 - D4 & 866 & 13.03 \\
\hline 5. & Bachelor's Degree (S1) & 2,904 & 43.70 \\
\hline 6. & Master's Degree (S2) & 585 & 8.80 \\
\hline 7. & Doctorate Degree (S3) & 7 & 0.11 \\
& Total & 6,644 & 100
\end{tabular}

Source: Statistics Indonesia (2016)

applied must be in accordance with the company's mission as outlined in the company's strategy and implemented in the company's operational activities. For that, an organization must have an organizational culture that is able to change attitudes and also employee behavior to be better in the form of work culture. This is reinforced by the opinion of Hatalea, Rusmiwari \& Aminulloh (2014, p. 9) that work culture has a primary goal to change attitudes and also human behavior so that in turn it can improve performance. Thus, the organization should emphasize the ability of human resources to work well.

The quality of human resources in Jambi Provincial Government is good enough, it can be seen that most civil servants have a bachelor's degree background, as many as 2,904 people (43\%), a master's degree background, as many as 585 or $(8.80 \%)$, and 7 people $(0.11 \%)$ of whom are of doctorate title (see Table 1).

Based on Table 1 above, it explains the level of civil servant's education in Jambi Province. In the table of civil servant's education level in Jambi Province, the most are bachelor's degree with $43.70 \%$, compared to the lower ones, which are Senior high school, Junior high school, or primary school. Even, civil servants with master's degree education are $8.80 \%$, and with doctorate degree are $0.11 \%$. If seen from the level of education, can be drawn a conclusion that the mastery of knowledge and intellectual level has been able to provide the foundation and capital to work better in providing services to the community. Thus, the level of education should describe the work culture and employee personalities that will ultimately impact on the performance of civil servants themselves.

This research puts organizational culture and Big Five Personality as a moderation variable, with the aim to see how far the role of organizational culture that has been created by each SKPD and Big Five Personality, which is manifested through personality of employees, can strengthen the influence of work culture on civil servant performance in Jambi Province Government. This is in accordance with the alleged hypothesis that organizational culture and Big Five Personality are able to strengthen the influence of work culture on the performance of civil servants in the government of Jambi Province. However, not all research results of organizational culture and Big Five Personality as a moderating variable can strengthen the influence of work culture on performance. Velen's research (2012, p. 44) explains that organizational culture is weakening the interaction between organizational commitment to performance. This is because the organizational culture created tends to make employees not free in performing their duties because of the tight bureaucracy. When employees feel uncomfortable and depressed, creativity is limited and causes the performance to decrease and vice versa.

The results of Suweno \& Rahadhini's research $(2012$, p. 70$)$ on organizational culture as a moderating variable are different from Velen's research results (2012, p. 44) The results of Suweno \& Rahadhini's research found that organizational culture as a moderating variable can strengthen the influence of transform leadership on performance. Furthermore, previous research on the effects of moderation effects found that Big Five Personality can strengthen or weaken the influence of work culture on performance. Until now, there is no study that discusses Big Five Personality as a moderating variable that can strengthen or enhance the influence of work culture on employee performance. As a moderating variable, it is expected that organizational culture and Big Five Personality can strengthen the interaction between work culture and performance so that work culture has a great contribution to improve civil servant performance in Jambi Province government. This study was conducted to measure the extent to which the Big Five Personality and organizational culture as a moderating variable can increase the influence of work culture on the performance of civil servants in the Government of Jambi Province.

Referring from the results of a provisional survey of public complaints on services provided by the civil servants Jambi Provincial Government, it reinforced the results of the Ombusdman survey (2017) and is supported by the research by Suweno 
\& Rahadhini (2012, p. 70), Velen (2012,p. 44) which explains the role of organizational culture and Big Five Personality as a moderating variable, the purpose of this research is to (1) to know the existing condition or condition of organizational culture, Big Five Personality, work culture and civil servant performance in Jambi Provincial Government (2) to observe the effect of moderation of organizational culture on work culture interaction and civil servant performance in Jambi Provincial Government, (2) Knowing the effect of Big Five Personality Modeling on the interaction of work culture and civil servant performance in Jambi Province Government.

Employee performance can be measured using several indicators, but many theories explain how to measure employee performance. This study in measuring employee performance uses the concept of theory from Muhammad (2009, p. 125), which describes some of the indicators used to measure employee performance, namely: (1). Understanding the main task (tupoksi). In running tupoksi, subordinates must first understand about the main tasks and functions of each and do the task in accordance with the responsibility. (2) Innovation. Have positive innovation and deliver to the superior and discuss it with colleagues about the work. (3) The speed of work. In running the task, the speed of work must be considered by using or following the existing work methods. (4) The accuracy of work. In doing the task, not only fast but in completing the task, employees must also be careful and do re-checking in every work done. (5) Cooperation. Ability in cooperation with colleagues and leaders, for example, can receive and appreciate the opinions of others.

Big five personality provides a framework of a comprehensive theory that aims to measure and determine one's personality (Kalshoven, Den Hartog, \& de Hoogh, 2011, p. 57). Big Five Personality is used to measure the personality of a person capable of influencing organizational performance (Nasyroh \& Wikansari, 2017, p. 15), and Personality has been used as a guide for researchers to continue previous research on extraversion, conscientiousness, openness to experience, neuroticism, and agreeableness and conclude that Big Five personality is needed by individuals who want to succeed in organizational business (Salter, Green, Duncan, Berre, \& Torti, 2010, p. 11). The personality that colored civil servants in Jambi Province has a close relationship with the performance results achieved. The results of Widhiastuti (2014, p. 130) conducted on civil servants in Central Java province found that the civil servant personality measured through Big Five personality has a relationship with performance. This study explains the Conscientiousness and Openness to Experiences factors that can support performance. Meanwhile, the Extraversion, Agreeableness and neuroticism factors do not support the performance.

\section{METHOD}

The process of collecting data uses survey research method, that is obtaining information by using the questionnaire as the main data picker in the selected sample representing the population. The type of research is descriptive to know the illustration of Organizational culture condition, Big Five personality, work culture and the performance of civil servants in Jambi Provincial Government at this time and the verificative research to explain the relations of influence between organizational culture and Big Five personality as moderating variables to strengthen or weaken the influence of organizational culture on performance.

The population in this study is all Civil Servants in the Local Government of Jambi Province that is in 27 SKPDs including agencies and 8 Bureaus and UPTD. In order to answer the research objectives, a representative sample of the population is drawn. Sampling is done gradually (stratified sampling). The first stage is done by selecting randomly one random sample representing SKPD, Agency, Bureau, and UPTD. The selected one to represent SKPD is Fisheries and Marine Office, to represent the Agency is the Research and Development of the region, to represent the Bureau is the Bureau of Organization and Cooperation, and to represent UPTD is Raden Mattaher General Hospital, Jambi. The number of samples for respondents is determined based on the Slovin formula with the degree of error of $10 \%$. Thus, obtained the number 234 on the third stage of respondents selected in SKPD, on Agency and Bureau, it is done by selecting using proportional stratified random sampling method. The reason for choosing this technique is to select selected samples from each representing the Office of Fisheries and Marine Affairs, Regional Research and Development Agency, Organization and Cooperation Bureau, and Raden Mattaher General Hospital with different data sample depending on population size. The sample is allocated proportionally to the sub-population based on the following formula:

$$
n_{1}=\frac{N_{1}}{N} \times n
$$

$N_{1}=$ Population per Office, Agency, Bureau, and UPTD

$N=$ Population of Office, Agency, Bureau, and UPTD

$N=$ The amount of determined sample

Data collection techniques are through questionnaires, interviews, observation, and documentation studies. Furthermore, the technique of data analysis is done using descriptive analysis approach and statistical/verificative 
analysis. Descriptive analysis is used to draw the extent of the condition of organizational culture, work culture, employee personality image, and employee performance, applied in the category of organizational culture is not strong, less strong, strong, very strong. Work culture is not good, less good, good, and very good. Personality is not good, less good, good, and very good and performance is not good, less good, good, and very good. To arrive at the criteria, then categorization is done into four categories using a range of scales, resulting in categorization for the following variables:

\begin{tabular}{cc} 
Value & Categorization \\
$234-409.5(25 \%-43.75 \%)$ & Not good/not strong \\
\hline$>409.5-585(>43.75 \%-62.5 \%)$ & Less good/less strong \\
\hline$>585-760.5(>62.5 \%-81.25 \%)$ & Good/strong \\
\hline$>760.5-936(>81.25 \%-100 \%)$ & Very good/very strong \\
\hline
\end{tabular}

The verificative analysis is used to determine the magnitude of influence between variables through hypothesis testing. Where the hypothesis is:

1. Allegedly, Organizational Culture strengthens the interaction between work culture and civil servant's performance in Jambi Provincial Government

2. Allegedly, Big Five Personality strengthens the interaction between work culture and civil servant's performance in Jambi Provincial Government. Statistical analysis used to test hypotheses in this study using path analysis.

\section{RESULTS AND DisCUSSION}

\section{A. Existing Conditions or Organizational Culture, Big Five Personality, Working Culture and Performance of Civil Servants in Jambi Provincial Government}

To see the cultural picture of the organization, then the measurement of organizational culture uses the indicator of Victor Tan concept as described in Wibowo (2011, p. 377) which consists of 10 dimensions and divided into indicators. The results of measurements of these indicators illustrate that in general, the organizational culture environment in Jambi provincial government has entered into a strong cultural category.

In general, an organizational culture based on the results of data has shown a strong culture, which contains rules, values, systems and various policies that lead to organizational performance. However, there are still some indicators that need to get attention with the achievement still below $70 \%$, which is Risk tolerance dimension, where still encountered PNS who do not dare to work with type of work which contain risk and in dimension of reward system, which explain about 32.5\% organizations in promoting their employees that are not based on work performance.

The illustration of Big Five personality variable as moderate variables, based on the results of the data is in a good category, but there are some indicators of concern, among other is the indicator that has a performance still below 70\%. For example, only $65 \%$ of employees are able to work in an unfavorable room, the rest of which $35 \%$ cannot work in an unfavorable room. Employees with loyalty to employment are of $68 \%$ and about $32 \%$ have no loyalty attitude to work, such as unwilling to come home late to finish the work that must be completed soon.

The illustration of Big Five personality variable as a moderated variable, based on the results of the data is in a good category, but there are some indicators of concern, among other is the indicator that has a performance below 70\%. For example, only $65 \%$ of employees are able to work in an unfavorable room, the rest of which 35\% cannot work in an unfavorable room. Employees with loyalty to employment are of $68 \%$ and about $32 \%$ have no loyalty attitude to work, such as unwilling to go home late to finish the work that has to be completed soon. The personality of the civil servants from the extroversion side that needs to be considered is a firm attitude in determining the choice, although the choice will be bad and the civil servants who have a firm personality like this are only about $66 \%$. This means that about $34 \%$ still have no firmness if faced with a decision. There are still about $33 \%$ of civil servants who are really unwilling to do the job assigned to them just because by they do not like the job.

The personality of civil servants from the side of agreeableness. The personality that needs to be improved is that about $33 \%$ of civil servants in Jambi Provincial Government who still do not want to do the job given when the work is not preferred. Approximately $31 \%$ feel aggrieved if the volume of work exceeds their co-workers'.

For the personality of neuroticism, what is improved is when the civil servants face the pressure of work, but can manage a stressful work pressure well, so it can improve performance, it turns out that the data of the person encountered is that about $37 \%$ of civil servants who have pressure in work to make them not eager in doing their job.

The most dominant and excellent personality attached to civil servants in Jambi Province based on the results of the data is Conscientiousness, which explains that about $98 \%$ of civil servants at work 
have a meticulous nature where they always reexamine every job done. Furthermore, on average, $82 \%$ of civil servants are able to accept criticism and $80 \%$ of civil servants are able to find alternatives or solutions to obstacles.

To see the work culture illustration, the work culture is measured by using the indicator of the concept of Ndraha (2010) consisting of 2 dimensions and divided into indicators which further the measurement results are grouped into categories of bad work culture, less good work culture, good work and very good work culture.

The illustration of civil servant's performance in Jambi Provincial Government which is assessed from 8 (eight) dimension has been in a good category. Whereas on average, about $79 \%$ of civil servants in the Jambi Provincial Government already understand their respective tupoksi, although about $21 \%$ are still working not in accordance with tupoksi, especially the coordination system is not going well, so the overlapping work is still common. The lowest performance of civil servants is their presence if invited to the meeting. There are about $74 \%$ who are always present in the meeting and about $26 \%$ of civil servants who are not present for various reasons.

\section{B. The Effect of Moderation in Organizational Culture on the Interaction of Work Culture and Performance of civil servants in Jambi Provincial Government}

The effect of moderation on organizational culture sees the interaction between work culture and civil servant performance, whether with moderation effect of organizational culture as moderation variable will strengthen the influence of

\section{Table 2.}

The Effect of Moderation in Organizational Culture on the Interaction of Work Culture and Performance of civil servants in Jambi Provincial Government

\begin{tabular}{|c|c|c|c|c|c|}
\hline \multirow{2}{*}{ Model } & \multicolumn{2}{|c|}{$\begin{array}{l}\text { Unstandardized } \\
\text { Coefficients }\end{array}$} & $\begin{array}{l}\text { Standardized } \\
\text { Coefficients }\end{array}$ & \multirow{2}{*}{$\mathbf{t}$} & \multirow{2}{*}{ Sig } \\
\hline & B & $\begin{array}{l}\text { Std. } \\
\text { Error }\end{array}$ & Beta & & \\
\hline $\begin{array}{l}\text { Organizational } \\
\text { Culture }\end{array}$ & 1.105 & .192 & & 5.745 & .000 \\
\hline Work Culture & .157 & .065 & .119 & 2.167 & .018 \\
\hline $\begin{array}{l}\text { Moderation } \\
\text { Effect }\end{array}$ & .482 & .055 & .224 & 3.733 & .000 \\
\hline $\begin{array}{l}\text { Organizational } \\
\text { Culture }\end{array}$ & .109 & .010 & .047 & 1.983 & .023 \\
\hline
\end{tabular}

work culture on the performance of civil servants, which can be seen from the results in Table 2 .

In Table 1, it explains the effect of moderation in which the statistical test results explain that partially, organizational culture itself has a positive and significant effect on the performance of civil servants $(0.119 \times 0.119)=1.4 \%$ this influence is very small, because about $98.6 \%$ is influenced by other variables outside this study. The small influence of organizational culture on employee performance is similar to the result of research which has been done by Prawesti (2010, p. 10) where the result of research finds the influence of organizational culture to the performance of $5.56 \%$ and about $94.44 \%$ are influenced by other variables. Aristayudha \& Netra (2013, p. 55) also found that the contribution of organizational culture to employee performance is only $8.46 \%$ and the remaining $91.54 \%$ of employee performance is more influenced by other variables. However, unlike the results of research conducted by Jusmin (2013, p. 13), the results of the study found that organizational culture contributed more to the performance of employees, which is about $56.3 \%$ compared to findings of research by (Aristayudha \& Netra, 2013; Prawesti, 2010).

Meanwhile, work culture has a direct influence on the performance of civil servants $(0.224 \mathrm{x}$ $0.224)=5.02 \%$. The work culture still has a small contribution to the performance of civil servants in Jambi Provincial Government. However, if the organizational culture is used as a moderating variable and interact with the work culture, it will give a positive and significant effect on the performance of $(0.047 \times 0.047)=0.22 \%$. The Value of $0.22 \%$ is smaller than the direct influence of organizational culture on performance. This means that moderation effects of organizational culture when interacting with work culture are not able to provide a strong effect to improve performance, meaning that organizational culture as a moderating variable weakens the interaction of influence between work culture and performance and the first hypothesis is not proven. The results of this study are in line with the results of research by Velen (2012, p. 44) which explains that organizational culture has weakened the interaction between organizational commitment (a description of work culture) to performance, this is because the organizational culture created tends to make employees feel burdened in performing their duties because of the tight bureaucracy. When employees feel uncomfortable and depressed, creativity is limited which then will cause the performance to decrease and vice versa. However, unlike Suweno \& Rahadhini's (2012, p. 70), the research result shows that organizational culture, as a moderating variable, strengthens the influence of transformed 
leadership (leadership is an illustration of work culture) on performance.

The result of this research gives meaning that organizational culture that has been embedded in the workplace in civil servants of Local Government of Jambi Province is that as a moderating variable, it will weaken the interaction of work culture to performance, because the contribution to performance is only about $0.22 \%$, compared to organizational culture itself, which directly influence the performance of $1.4 \%$ or the work culture itself directly by $5.02 \%$.

The result of this study illustrates that organizational culture is a set of rules, which governs human behavior in organizations and contains values, beliefs, teachings, and guidelines that shape how humans behave in organizations (Wilson, 2010) and work culture is a reflection or reflection of organizational culture manifested in the form of how employees act and behave at work. The result of the research turns out that when organizational culture is still in the form of rules, values, and guidance of employees in working as moderation variable is weak in the influence of the relationship between work culture and employee performance. Thus, the organizational culture as a supporter (determinant) in order to play a role to strengthen the relationship between work culture and performance must be adjusted to the culture, personality, and behavior of the employees, so that the existing organizational culture in the civil servants of the Government of Jambi Province can influence the behavior of the people working to achieve the organization goal.

\section{The Effect of Big Five Personality Moderation to the Interaction between Big Five Personality and Work Culture on the Performance of Civil Servants of Jambi Provincial Government}

The effect of Big Five Personality moderation sees the interaction between work culture and the performance of Civil Servants, whether with the effect of moderation where Big Five Personality as a moderation variable will strengthen the work culture on the performance of civil servants can be seen on the results below:

Figure 2 illustrates the effect of moderation in which the statistical test shows a result that partially, Big Five Personality has a positive and significant effect on the performance of civil servants $(0,522 \times 0.522)=27.25 \%$. Big Five Personality's influence on performance is greater than the organizational culture on performance that is only $1.4 \%$. Meanwhile, Work Culture has a direct influence on the performance of civil servants of $5.02 \%$. The work culture still has a small
Table 3.

The Effect of Moderation in Organizational Culture on the Interaction of Work Culture and Performance of civil servants in Jambi Provincial Government

\begin{tabular}{|c|c|c|c|c|c|}
\hline \multirow{2}{*}{ Model } & \multicolumn{2}{|c|}{$\begin{array}{l}\text { Unstandardized } \\
\text { Coefficients }\end{array}$} & \multirow{2}{*}{$\begin{array}{c}\text { Standardized } \\
\text { Coefficients } \\
\text { Beta }\end{array}$} & \multirow{2}{*}{$\mathbf{t}$} & \multirow{2}{*}{ Sig } \\
\hline & B & $\begin{array}{l}\text { Std. } \\
\text { Error }\end{array}$ & & & \\
\hline $\begin{array}{l}\text { Big Five } \\
\text { Personality }\end{array}$ & .666 & .168 & & 4.015 & .000 \\
\hline Work Culture & .594 & .081 & .522 & 7.317 & .018 \\
\hline $\begin{array}{l}\text { Moderation } \\
\text { Effect }\end{array}$ & .226 & 0.61 & .224 & 3.688 & .000 \\
\hline $\begin{array}{l}\text { Big Five } \\
\text { Personality }\end{array}$ & .129 & .009 & .709 & 14.113 & .000 \\
\hline
\end{tabular}

contribution to the performance of civil servants in Jambi Provincial Government. However, if Big Five Personality is used as a moderating variable, then Big Five Personality can strengthen the influence of interaction relationship between work culture and performance, which produces a positive and significant influence on the work culture performance $(0.709 \times 0.709)=50.27 \%$. The value of $50.27 \%$ greater than the Big Five Personality influence directly to performance. This means that the moderate effect of Big Five Personality when interacting with work culture will be able to give a strong effect (the second hypothesis proved) to improve the performance compared to moderation effects of organizational culture while interacting with work culture.

The results of the study found that the basic personality owned by civil servants, in general, is good. Muhsin \& Sutomo (2015, p. 47) explains that personality is a character in a relatively permanent, persisting individual that affects the individual's self-adjustment to the environment. Referring to the opinion of Muhsin \& Sutomo (2015, p. 49), linked statistical results of organizational culture as moderating variables that weakens the interaction between work culture and performance versus big five personality statistics results in strengthening the interaction of work culture and performance. The results of these statistical tests empirically have depicted the culture described through rules and symbols for altering civil servants to behave in accordance with rules, systems, values established by the organization, although the small cultural contribution affects the performance of only about $1.4 \%$ and as the moderating variables weaken the interaction of work culture and performance, it turns out that the civil servant of Jambi Province 
already has a good personality, measured through personality theory about extraversion, conscientiousness, openness to experience, neuroticism, and agreeableness and concludes that the Big Five personality is needed by individuals who want success in the business organization (Salter et al., 2010, p. 11).

The personality that colored the civil servants in Jambi Province has a relationship to performance through the direct influence on the performance, which contributes up to $27.25 \%$ and the personality (Big Five Personality), as a moderating variable, is able to strengthen the interaction between work culture and performance by $50.27 \%$. Organizational culture should also be able to strengthen theinfluence of work culture on performance because the content of organizational culture will form the people in the organization to behave or have a personality at work. Thus, the need to be re-examined whether the organizational culture applied within the civil servant Jambi is in accordance with the conditions, the development of the external environment, and the character of civil servants encountered. This is supported by the opinion of Kreitner and Angel in Wibowo (2011, p. 377), which stated that one of the cultural factors that can improve the company's performance is a fit perspective, based on the premise that organizational culture must be aligned with the business context or strategy. For example, Standardized and planning cultures may work well in slow-working industries, but they do not fit in Internet companies that work in a very high change and changing environments. Conversely, a culture where individualized performance is valued can help sales organizations but will undermine performance in organizations where people work in teams. Thus, according to Kreitner and Angel, there is no single best culture, each culture will give a good influence, if adjusted to the conditions under which the culture is placed, the performance of the company will achieve results if it is appropriate with the context.

\section{Conclusion}

Based on the results of the discussion in the study, it is concluded; (1), the existing condition of organizational culture, big five personalities, work culture and the performance of employees in Jambi Provincial Government are already in a good category; (2) The moderating effects of organizational culture weaken the interaction between work culture and performance. It turns out that the moderating variables of organizational culture contribute less to the performance than the contribution of organizational culture and work culture partially to the performance; (3) The moderate effect of Big Five Personality strengthens the interaction between work culture and performance, as the moderate variable Big Five Personality contributes more to performance than Big Five Personality's contribution and work culture partially to performance. For that reason, the Local Apparatus Cooperation Unit (SKPD), the Agency, Bureau, and UPTD need to strengthen the organizational culture through strengthening the ability of leaders to build the personality of civil servants, so as to reflect the habits in working through attitudes and work behavior by improving the personality of civil servants in the form of having loyalty in work, consistent, committed, firm and creative. Each SKPD, agency, Bureau and UPTD reassess whether the organizational culture that has been applied is in accordance with the conditions of the external environment and the character of employees in the workplace environment, so that the organizational culture that will be implemented in the form of work culture can be tailored to the employee's personality and external circumstances demands.

\section{ACKNOWLEDGEMENT}

The author expressed her gratitude to Balitbangda Jambi Province which has provided the fund in this research. Acknowledgments are also expressed to SKPDs that have represented and selected as the sample, namely the Department of Fisheries and Marine of Jambi Province, Research and Development Agency of Jambi province, Bureau of Administration and Cooperation and General Hospital Raden Mattaeher Jambi which have helped the conduction of the research activities so that this study can be completed properly.

\section{REFERENCES}

Aristayudha, A. A. N. B., \& Netra, I. G. S. K. (2013). Pengaruh Budaya Organisasi, Kepemimpinan dan Motivasi terhadap Kinerja Karyawan pada PT BPD Bali Cabang Renon. E-Jurnal Manajemen Universitas Udayana, 2(7), 831844. Retrieved from https://ojs.unud.ac.id/ index.php/Manajemen/article/view/5445

Dahmiri. (2014). Analisa Kepuasan Masyarakat terhadap Kinerja Pelayanan Kantor Camat Kecamatan Sarolangun. Jurnal Studi Manajemen, 8(2), 132-144. Retrieved from http://journal.trunojoyo.ac.id/kompetensi/ article/view/654

Direktorat Aparatur Negara Kementerian Perencanaan Pembangunan Nasional/ BAPPENAS. (2010). Manajemen Pengaduan Masyarakat dalam Pelayanan Publik. Laporan Kajian. Jakarta: Bappenas.

Hatalea, A., Rusmiwari, S., \& Aminulloh, A. (2014). Budaya Kerja Pegawai Negeri Sipil. JISIP: Jurnal Ilmu Sosial Dan Ilmu Politik, 3(2), 6-10. 
Retrieved from https://publikasi.unitri.ac.id/ index.php/fisip/article/view/73

Jusmin, A. (2013). Analisis Pengaruh Budaya Organisasi terhadap Kinerja Pegawai pada Kantor Administrasi Perhubungan Jayapura. Future: Jurnal Manajemen Dan Akuntansi, 1(1).

Kalshoven, K., Den Hartog, D. N., \& de Hoogh, A. H. B. (2011). Ethical Leader Behavior and Big Five Factors of Personality. Journal of Business Ethics, 100(2), 349-366. http://doi. org/10.1007/s10551-010-0685-9

Liana, L. (2009). Penggunaan MRA dengan SPSS untuk Menguji Pengaruh Variabel Moderating terhadap Hubungan antara Variabel Independen dan Variabel Dependen. Jurnal Teknologi Informasi DINAMIK, XIV(2), 90-97. Retrieved from http://www.unisbank.ac.id/ ojs/index.php/fti1/article/view/95

Margaretha, M., \& Natalia. (2012). Pengaruh Sikap Kerja Terhadap Kinerja Karyawan pada PT. Duta Marga Silima di Jakarta. Jurnal Manajemen Dan Bisnis, 2(2), 151-166. Retrieved from http://jurnal.ubl.ac.id/index.php/jmb/ article/view/248

Muhammad, F. (2009). Reinventing Local Government: Pengalaman dari Daerah. Jakarta: Elex Media Komputindo.

Muhsin, N., \& Sutomo, Y. (2015). Pengaruh Kepribadian dan Motivasi Kerja terhadap Kinerja Guru Dimoderasi Budaya Organisasi pada Madrasah Tsanawiyah Swasta Kecamatan Winong Kabupaten Pati. Jurnal Mahasiswa Pasca Sarjana. Retrieved from https://www. unisbank.ac.id/ojs/index.php/pasca1/article/ view/3245

Nasyroh, M., \& Wikansari, R. (2017). Hubungan Antara Kepribadian (Big Five Personality Model) dengan Kinerja Karyawan. Jurnal Ecopsy, 4(1), 10-16. Retrieved from http:// ppjp.unlam.ac.id/journal/index.php/ecopsy/ article/view/3410

Ndraha, T. (2010). Budaya Organisasi. Jakarta: Rineka Cipta.

Prawesti, S. D. (2010). Pengaruh Pengukuran Kinerja, Budaya Organisasi dan Dukungan
Organisasional terhadap Kinerja Pegawai di Unit-unit Pelayanan Publik Kabupaten Sukoharjo. Sebelas Maret University.

Ratuwalangon, F. I., Tulusan, F., \& Londa, V. (2017). Penanganan Keluhan Publik di Kantor Dinas Kependudukan dan Pencatatan Sipil Kabupaten Minahasa Utara (Studi pada Pelayanan E-KTP). Jurnal Administrasi Publik, 3(46). Retrieved from https://ejournal.unsrat.ac.id/index.php/ JAP/article/view/16299

Salter, C., Green, M., Duncan, P., Berre, A., \& Torti, C. (2010). Virtual communication, transformational leadership, and implicit leadership. Journal of Leadership Studies, 4(2), 6-17. http://doi.org/10.1002/jls.20164

Suryadi. (2010). Penanganan Keluhan Publik pada Birokrasi Dinas Perijinan. Masyarakat, Kebudayaan Dan Politik, 23(4), 293-303.

Suweno, \& Rahadhini, M. D. (2012). Efek Moderasi Budaya Organisasi pada Pengaruh Kepemimpinan Transformasional terhadap Kinerja. Jurnal Manajemen Sumber Daya Manusia, 6(1), 58-71. Retrieved from http:// ejurnal.unisri.ac.id/index.php/Manajemen/ article/view/504

Velen, L. (2012). Peran Budaya Organisasi dalam Memoderasi Pengaruh Komitmen Organisasi terhadap Kinerja Karyawan: Studi pada Karyawan Cleaning Service PT. ISS Indonesia. Kajian Ilmiah Mahasiswa Manajemen, 1(1), 4045. Retrieved from http://jurnal.wima.ac.id/ index.php/KAMMA/article/view/63

Wibowo. (2011). Budaya Organisasi: Sebuah Kebutuhan untuk Meningkatkan Kinerja Jangka Panjang. Jakarta: Rajawali.

Widhiarso, W. (2011). Berkenalan dengan Variabel Moderator. Fakultas Psikologi UGM.

Widhiastuti, H. (2014). Big Five Personality sebagai Prediktor Kreativitas dalam Meningkatkan Kinerja Angggota Dewan. Jurnal Psikologi, 41(1), 115-133. http://doi.org/10.22146/ jpsi.6962

Wilson, F. M. (2010). Organizational Behaviour and Work: A Critical Introduction (3rd ed.). Oxford: Oxford University Press. 